\title{
Molybdenum(III) Thiocyanate- and Selenocyanate-Based 1D-Heteronuclear Polymers: Coordination Affinity-Controlled Assemblage of Mixed Spin and Mixed Valence Derivatives with $\mathrm{Ni}(\mathrm{II})$ and $\mathrm{Co}(\mathrm{II} / \mathrm{III})$
}

Malihe Mousavi, ${ }^{\mathrm{a}}$ Carine Duhayon, ${ }^{\mathrm{a}}$ Kateryna Bretosh, ${ }^{\mathrm{a}}$ Virginie Béreau*a,b , Jean-Pascal Sutter*a

${ }^{a}$ Laboratoire de Chimie de Coordination (LCC) du CNRS, Université de Toulouse, CNRS, F-31077 Toulouse, France

b Université de Toulouse, Institut Universitaire de Technologie Paul Sabatier, Département de Chimie, F-81104 Castres, France

Scheme S1. Sketch of macrocyclic ligand 2,12-dimethyl-3,7,11,1-tetraazabicyclo [11.3.1]-heptadeca-1(17),2,11,13,15 pentaene, $\mathrm{L}^{\mathrm{N} 4}$.

Figure S1 ORTEP view of the asymmetric unit of $1 \mathrm{D}-\left[\left\{\mathrm{Mo}(\mathrm{NCS})_{6}\right\}\left\{\mathrm{Ni}(\mathrm{en})_{2}\right\}\right] \cdot 0.5\left\{\mathrm{Ni}(\mathrm{en})_{3}\right\} \cdot 0.5 \mathrm{H}_{2} \mathrm{O}, 1$.

Figure S2 Organization of $\mathbf{1}$ in the crystal.

Figure S3 ORTEP view of the asymmetric unit of 1D-[ $\left.\left\{\mathrm{Mo}(\mathrm{NCS})_{6}\right\}\left\{\mathrm{NiL}^{\mathrm{N} 4}\right\}\right] \cdot 0.5\left\{\mathrm{NiL}^{\mathrm{N}} 4(\mathrm{CH})_{2}\right\} \cdot 0.5 \mathrm{CH}_{3} \mathrm{CN} \cdot \mathrm{H}_{2} \mathrm{O}, 2$

Figure S4 ORTEP view of the asymmetric unit of $1 \mathrm{D}-\left[\left\{\mathrm{Mo}(\mathrm{NCS})_{6}\right\}\left\{\mathrm{NiL}^{\mathrm{N} 4}\right\}\right] \cdot\left\{\mathrm{Co}^{\mathrm{III}} \mathrm{L}^{\mathrm{N} 4} \mathrm{Br}_{2}\right\} \cdot, \mathbf{3}$.

Figure S5 ORTEP view of the asymmetric unit of $1 \mathrm{D}-\left[\left\{\mathrm{Mo}(\mathrm{NCS})_{6}\right\}\left\{\mathrm{CoL}^{\mathrm{N} 4}\right\}\right] \cdot\left\{\mathrm{Co}^{\mathrm{III}} \mathrm{L}^{\mathrm{N} 4} \mathrm{Br}_{2}\right\} \cdot, 4$

Figure S6 Detail of the $\pi-\pi$ stacking between chains in $\mathbf{3}$ and $\mathbf{4}$.

Figure S7 ORTEP view of the asymmetric unit of 1D-[ $\left.\left\{\mathrm{Mo}(\mathrm{NCS})_{6}\right\}\left\{\mathrm{CoL}^{\mathrm{N} 4}\right\}_{2}(\mathrm{NCS})\right] \cdot \mathrm{CH}_{3} \mathrm{CN}, \mathbf{5}$.

Figure S8 ORTEP view of the asymmetric unit of $\left[\mathrm{PPh}_{4}\right]_{3}\left\{\mathrm{Mo}(\mathrm{NCSe})_{6}\right\} \cdot \mathrm{CH}_{3} \mathrm{CN}$.

Figure S9 Ladder type organization of the $\left\{\mathrm{Mo}(\mathrm{NCSe})_{6}\right\}^{3-}$ complexes in the crystal of $\left(\mathrm{PPh}_{4}\right)_{3}\left\{\mathrm{Mo}(\mathrm{NCSe})_{6}\right\} \cdot \mathrm{CH}_{3} \mathrm{CN}$, Figure S10 ORTEP view of the asymmetric unit of $1 \mathrm{D}-\left[\left\{\mathrm{Mo}(\mathrm{NCSe})_{6}\right\}\left\{\mathrm{NiL}^{\mathrm{N} 4}\right\}_{2}(\mathrm{NCS})\right] \cdot \mathrm{CH}_{3} \mathrm{CN}, \boldsymbol{6}$.

Table 1 Spin density distribution in $\left[\mathrm{Mo}(\mathrm{NCSe})_{6}\right]^{3-}$

Figure S11 Experimental ( $(\circ)$ and calculated ( -$) \chi_{M} T$ versus $T$ behavior for $\left[\mathrm{PPh}_{4}\right]_{3}\left\{\mathrm{Mo}(\mathrm{NCSe}\}_{6} \cdot \mathrm{CH}_{3} \mathrm{CN}\right.$

Figure S12 Field dependence of the magnetization for 1, at $2 \mathrm{~K}$.

Figure S13 Field dependence of the magnetization for 2 , at $2 \mathrm{~K}$.

Figure S14 Compound 3: (left) $\chi_{\mathrm{M}}=f(T)$, and (right) field dependence of the magnetization..

Figure S15 Compound 4: (a) $\chi_{\mathrm{M}}=f(T)$, and (b) field dependence of the magnetization; (c) temperature dependence of AC susceptibility

Figure S16 Field dependence of the magnetization for 5, at $2 \mathrm{~K}$.

Figure S17 Field dependence of the magnetization for $\mathbf{6}$, at $2 \mathrm{~K}$.

Figure S18. Magnetic behaviour for $\left[\mathrm{CoL}^{\mathrm{N} 4}\left(\mathrm{H}_{2} \mathrm{O}\right)_{2}\right] \cdot 2 \mathrm{ClO}_{4}$.

Figure S19. Powder X-Ray patterns for 2-5.

Gaussian reference. 
Scheme S1. Sketch of macrocyclic ligand 2,12-dimethyl-3,7,11,1-tetraazabicyclo [11.3.1]heptadeca-1(17),2,11,13,15-pentaene, $\mathrm{L}^{\mathrm{N} 4}$.

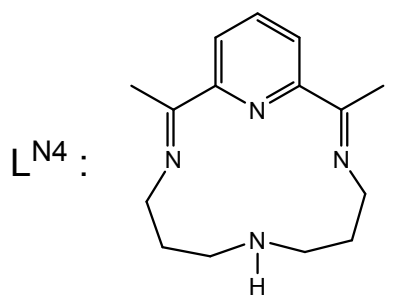

Figure S1. 1D-[\{Mo(NCS $\left.\left.)_{6}\right\}\left\{\mathrm{Ni}(\mathrm{en})_{2}\right\}\right] \cdot 0.5\left\{\mathrm{Ni}(\mathrm{en})_{3}\right\} \mathrm{H}_{2} \mathrm{O}, 1$ : ORTEP view of the asymmetric unit. Selected bond lengths $(\AA)$ and angles $\left(^{\circ}\right)$ patterning to the anionic units: distances $(\AA)$ Mo1-N2, 2.088(5); Mo1-N1, 2.096(5); Ni1*-S2, 2.578(2); Ni1-S1 = 2.624(1); angles $\left({ }^{\circ}\right)$ Ni1-S2-C2, 104.54(18); Ni1-S1-C1, 92.109(17); Mo1-N1-C1, 171.995(42); Mo1-N2$\mathrm{C} 2,172.770(40) . \mathrm{H}$ atoms are not shown. Symmetry: *, $x,-y,-0.5+z$.

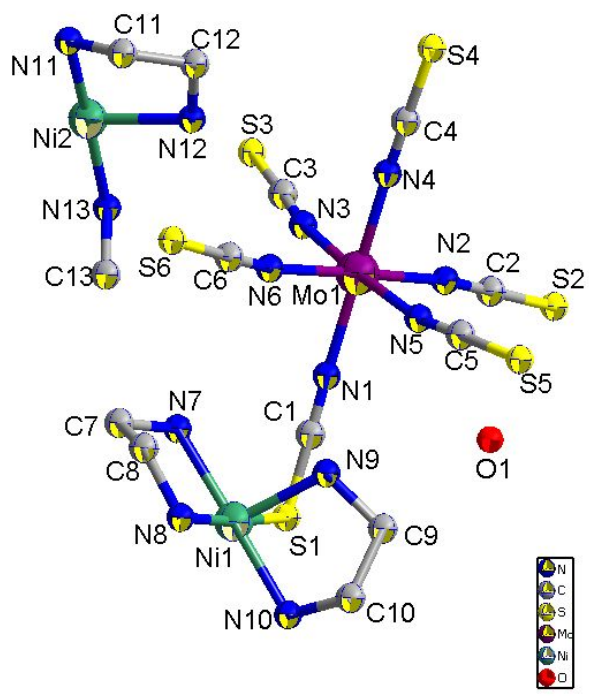


Figure S2 Crystal packing for 1. (right) Close contacts between chains; the shortest S $\cdots S$ separations are materialized by dotted lines. Distances $(\AA): \mathrm{S} 2 \cdots \mathrm{S} 2,3.92 ; \mathrm{S} 2 \cdots \mathrm{S} 3,3.73 ; \mathrm{S} 4 \cdots \mathrm{S} 3$, 3.72 .
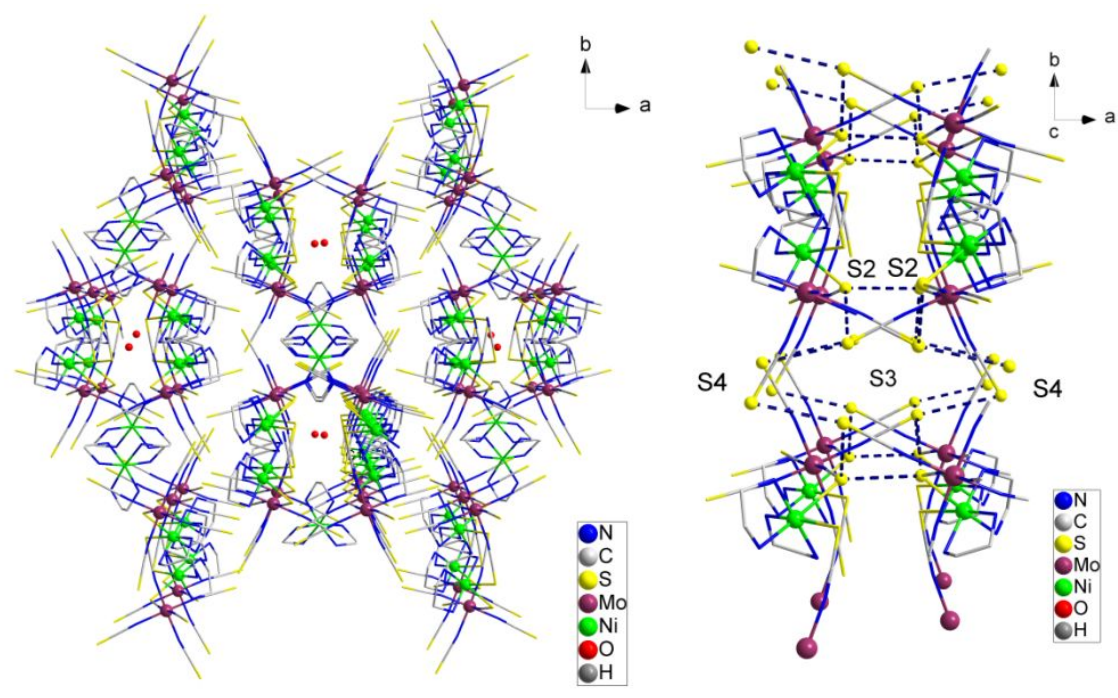

Figure S3. 1D-[ $\left.\left\{\mathrm{Mo}(\mathrm{NCS})_{6}\right\}\left\{\mathrm{NiL}^{\mathrm{N} 4}\right\}\right] \cdot 0.5\left\{\mathrm{NiL}^{\mathrm{N}} 4\left(\mathrm{CH}_{3} \mathrm{CN}\right)_{2}\right\} \cdot 0.5 \mathrm{CH}_{3} \mathrm{CN} \cdot \mathrm{H}_{2} \mathrm{O}, 2$ : ORTEP view of the two asymmetric units.
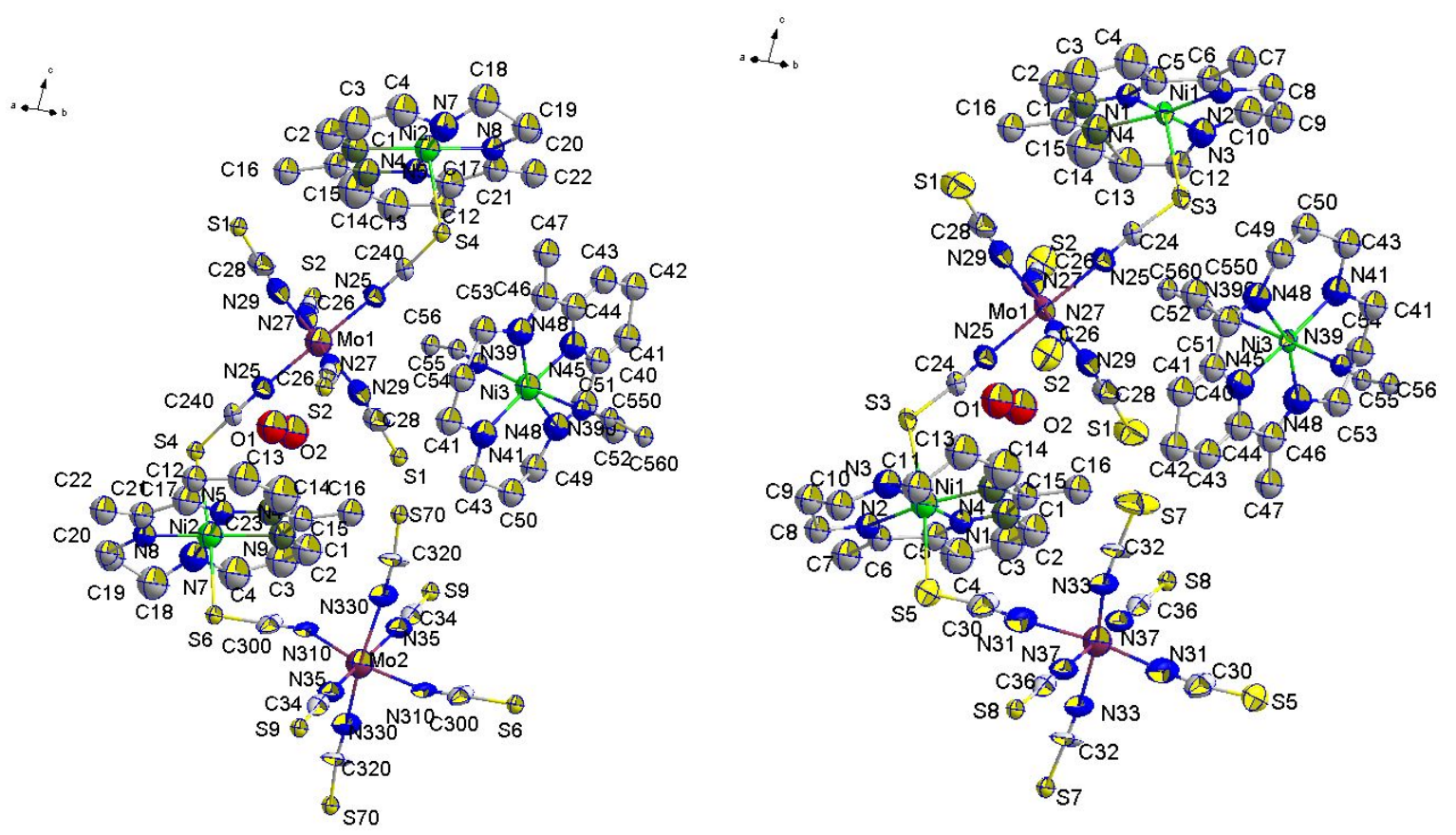

The structure for 2 presents a statistic disorder that concerns most of the atoms; a short description of the situation is given below. Diffraction data were collected on several crystals from different batches. The same cell parameters were obtained, leading to the same structure with the same 
disorders. Careful examination of the reciprocal lattice didn't permit to get other cell parameters. Refinement of the final formulated model leads to an imperfect but reasonable solution.

Oddly, Mo2 is not located on the special position $(0,1,0.5)$, as a result Mo resides on two positions with a partial occupancy. The thiocyanates with partial occupancy were located for each Mo position.

The Nickel atom is also located on two positions with partial occupation (Ni1 and Ni2). Each Ni is surrounded by its ligand which is present in full in the asymmetric unit. Some atoms (C2 C3 C4 $\mathrm{C} 13 \mathrm{C} 14 \mathrm{C} 15 \mathrm{C} 16)$ are common to the two ligands (occupancy 1). Other atoms have partial occupancy whereas $\mathrm{C} 23 / \mathrm{N} 4$ and $\mathrm{C} 1 / \mathrm{N} 9$ have mixed positions.

A view of this situation is depicted in (a) below.

(a)

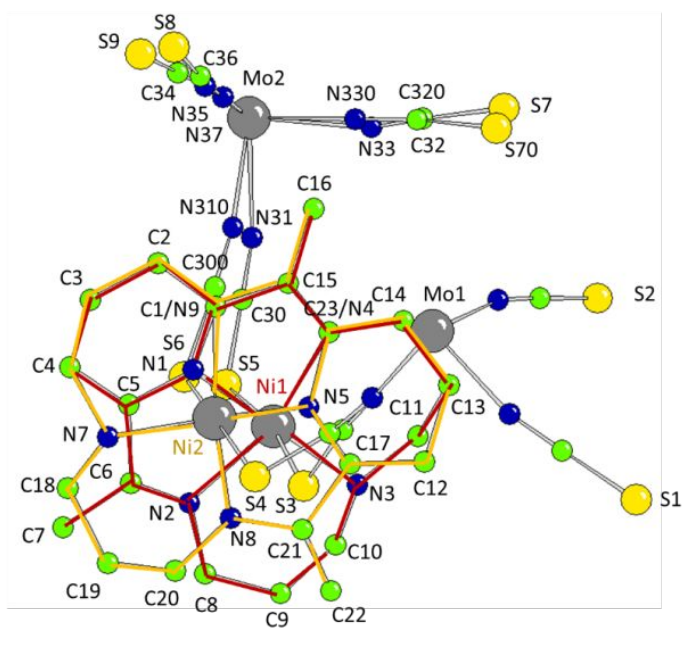

(b)

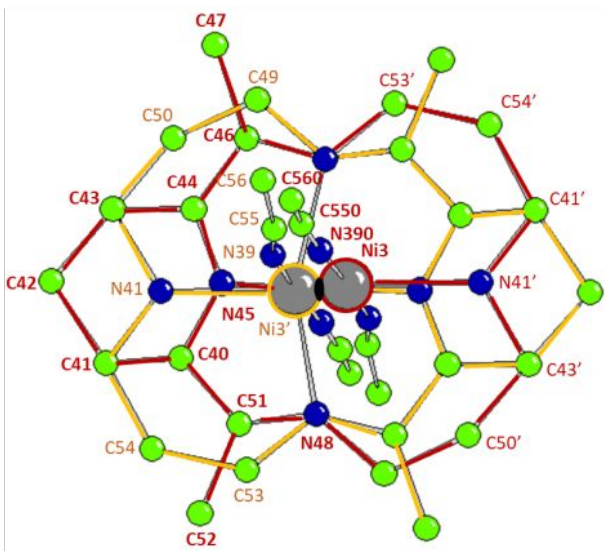

For the discrete fragment: Ni3 has a half occupancy and is located at $0.4 \AA$ from the inversion center $(-0.5,1,1)$. Ni3' is generated by the symmetry center. The atomic positions of the ligand around Ni3 and Ni3' were located by Fourrier difference. Most of the atoms have occupancy 0.5 (belonging to one of the 2 parts of the ligand). 3 atoms (N48, C41 and C43) have occupancy 1 (belonging to the 2 parts of the ligand). A view of a whole complex after symmetry what applied is given in (b) above. 
Figure S4. 1D-[ $\left.\left\{\mathrm{Mo}(\mathrm{NCS})_{6}\right\}\left\{\mathrm{NiL}^{\mathrm{N} 4}\right\}\right] \cdot\left\{\mathrm{Co}^{\mathrm{III}} \mathrm{L}^{\mathrm{N}} \mathrm{Br}_{2}\right\} \cdot \mathrm{CH}_{3} \mathrm{CN}, 3$ : ORTEP view of the asymmetric unit. Selected bond lengths $(\AA)$ and angles $\left({ }^{\circ}\right)$ : distances $(\AA)$ Co1-Br1, 2.413(2); Co1$\mathrm{Br}$ 2, 2.381(2); Ni1-S2, 2.561(2); Ni1-S1, 2.645(2); Mo1-N2, 2.083(5); Mo1-N1, 2.114(5); angles $\left(^{\circ}\right)$ Ni1-S2-C2, 108.65(2); Ni1-S1-C1,103.27(2); Mo1-N1-C1, 167.810(43); Mo1-N2-C2, 176.279(43); Br1-Co1-Br2, 179.710(75).
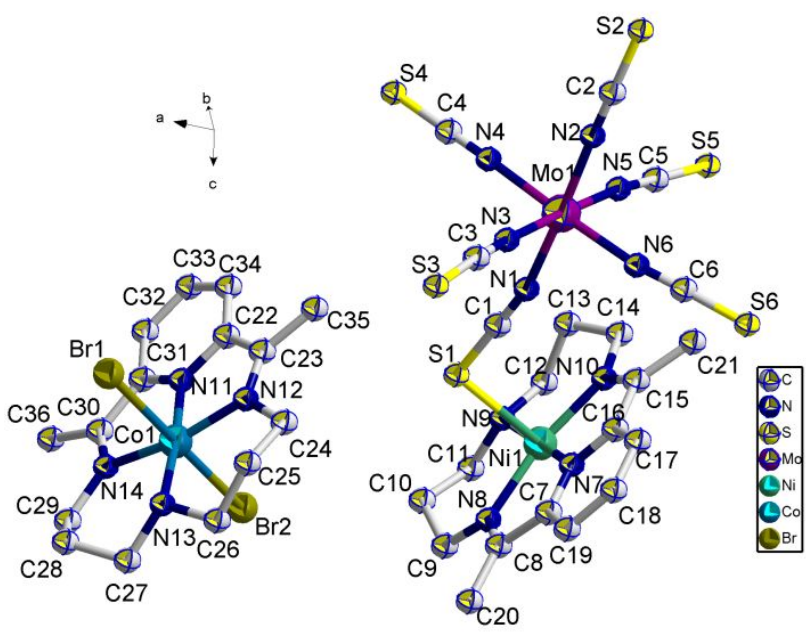

Figure S5. 1D-[ $\left.\left\{\mathrm{Mo}(\mathrm{NCS})_{6}\right\}\left\{\mathrm{CoL}^{\mathrm{N} 4}\right\}\right] \cdot\left\{\mathrm{Co}^{\mathrm{III}} \mathrm{L}^{\mathrm{N} 4} \mathrm{Br}_{2}\right\} \cdot \mathrm{CH}_{3} \mathrm{CN}, 4$ : ORTEP view of the asymmetric unit.

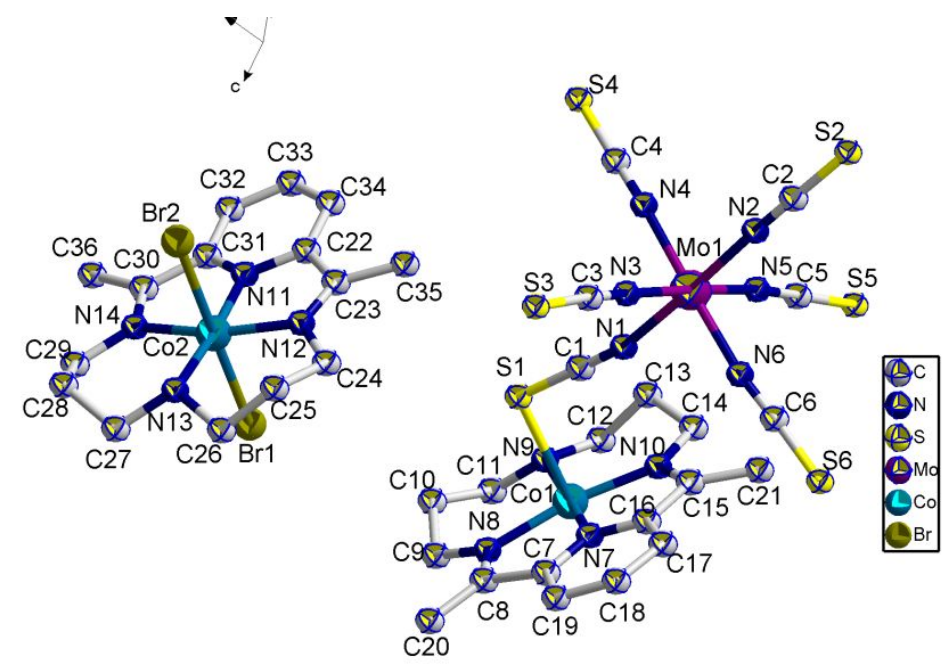

Selected bond distances $(\AA)$

$\begin{array}{lllllll}\text { Co1 } & \text { N7 } & 1.8286(84) & \text { Co1 } & \text { S1 } & \text { C1 } & 102.6(3) \\ & \text { N10 } & 1.9338(64) & \text { Co1 } & \text { N2 } & \text { C2 } & 108.4(2) \\ & \text { N9 } & 1.9830(84) & \text { Mo1 } & \text { N1 } & \text { C1 } & 167.9(6) \\ & \text { N8 } & 1.9838(70) & \text { Mo1 } & \text { N2 } & \text { C2 } & 176.4(6) \\ & \text { S2 } & 2.5767(25) & & & & \\ & \text { S1 } & 2.6897(26) & & & & \\ \text { Co2 } & \text { N11 } & 1.8406(59) & \text { Br1 } & \text { Co2 } & \text { Br2 } & 179.66(7) \\ & \text { N12 } & 1.9420(63) & & & & \\ & \text { N13 } & 1.9741(86) & & & & \\ & \text { N14 } & 1.9888(68) & & & & \end{array}$


Figure S6. Detail of the $\pi-\pi$ stacking between chains in 3 and 4 . Distances between the centroids of the pyridine units: in 3 for $\mathrm{NiL}^{\mathrm{N} 4}$ and $\mathrm{Co}^{\mathrm{II}} \mathrm{L}^{\mathrm{N} 4} \mathrm{Br}_{2}: 4.078(\AA)$; $\mathrm{NiL}^{\mathrm{N} 4}$ and $\mathrm{NiL}^{\mathrm{N} 4}$ : $4.008(\AA)$; in 4 $\mathrm{Co}^{(\mathrm{II})} \mathrm{L}^{\mathrm{N} 4} / \mathrm{Co}^{(\mathrm{III})} \mathrm{L}^{\mathrm{N} 4} \mathrm{Br}_{2}, 4.093(\AA)$, and $\mathrm{Co}^{(\mathrm{II})} \mathrm{L}^{\mathrm{N} 4} / \mathrm{Co}^{(\mathrm{II})} \mathrm{L}^{\mathrm{N} 4}, 4.027(\AA)$.

(3)

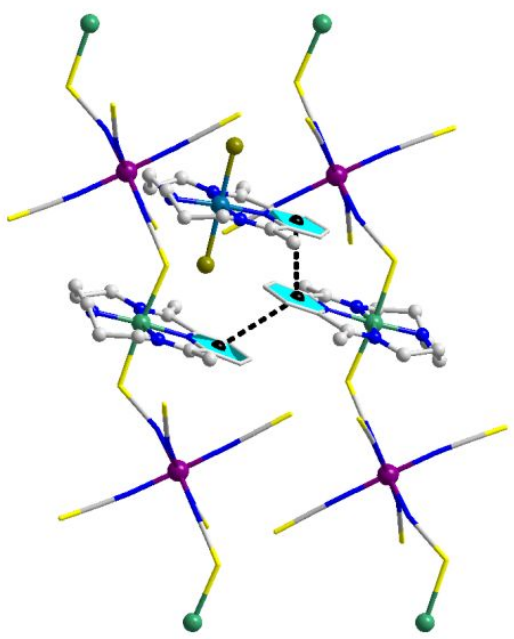

(4)

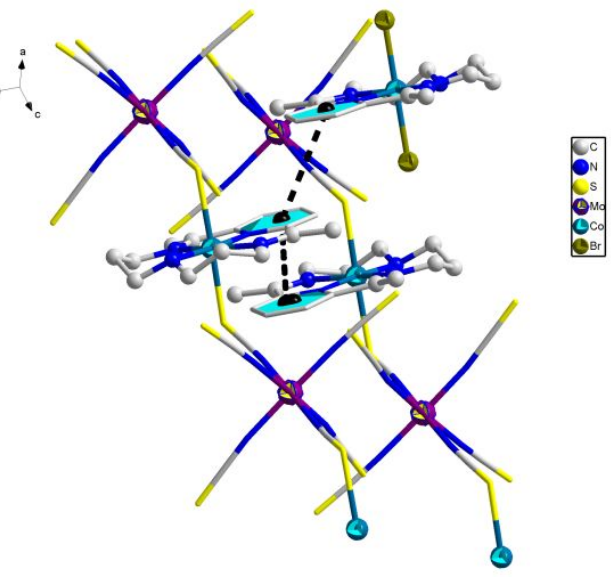


Figure S7. 1D-[ $\left.\left\{\mathrm{Mo}(\mathrm{NCS})_{6}\right\}\left\{\mathrm{CoL}^{\mathrm{N} 4}\right\}_{2}(\mathrm{NCS})\right] \cdot \mathrm{CH}_{3} \mathrm{CN}$, 5: (left) ORTEP view of the asymmetric unit at $T=110 \mathrm{~K}$ and (right) superposition of the asymmetric units at $T=273 \mathrm{~K}$ (ellipsoids at the $30 \%$ probability level) and $100 \mathrm{~K}$ (ball and sticks in green). This last drawing is the inverted image of the actual structure to have the same enantiomer as that of the crystal collected at $273 \mathrm{~K}$.
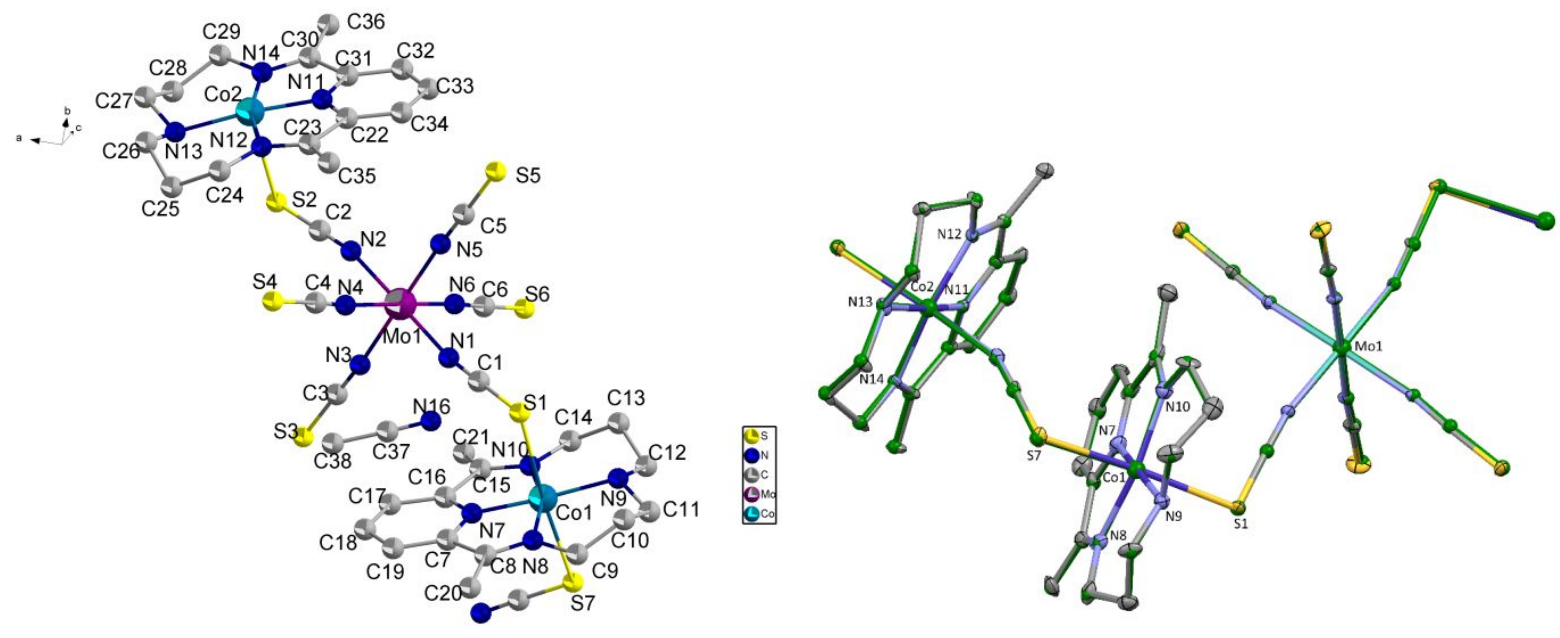

Selected bond distances $(\AA)$ and angles $\left(^{\circ}\right)$ :

\begin{tabular}{llll} 
& & \multicolumn{1}{c}{ C100K } & \multicolumn{1}{c}{$\mathbf{T = 2 7 3 K}$} \\
No1 & $1.839(6)$ & $1.840(4)$ \\
N10 & $1.910(5)$ & $1.921(4)$ \\
N9 & $1.987(5)$ & $1.981(4)$ \\
N8 & $2.019(5)$ & $2.014(4)$ \\
S7 & $2.563(2)$ & $2.590(1)$ \\
S1 & $2.632(2)$ & $2.670(1)$ \\
Co2 & N11 & $1.854(5)$ & $1.844(4)$ \\
N12 & $1.962(5)$ & $1.943(4)$ \\
N13 & $1.982(5)$ & $1.977(4)$ \\
N14 & $1.985(4)$ & $1.997(4)$ \\
N15 & $2.146(5)$ & $2.161(4)$ \\
S2 & $2.710(2)$ & $2.757(2)$ \\
& & \\
& & $\mathbf{1 1 0} \mathbf{K}$ & $\mathbf{2 7 3 ~ K}$ \\
Co1 & $103.7(2)^{\circ}$ & $104.3(1)^{\circ}$ \\
Co1 & $102.0(2)$ & $101.7(1)^{\circ}$ \\
Co2* & $104.5(2)^{\circ}$ & $105.1(1)^{\circ}$ \\
Mo1 & $169.5(4)^{\circ}$ & $169.5(3)^{\circ}$ \\
Mo1 & $166.6(4)^{\circ}$ & $167.2(3)^{\circ}$ \\
Mo1 & $173.3(5)^{\circ}$ & $173.7(4)^{\circ}$ \\
Mo1 & $177.0(4)^{\circ}$ & $176.5(4)^{\circ}$ \\
Mo1 & $172.6(4)^{\circ}$ & $173.2(3)^{\circ}$ \\
Mo1 & $177.0(4)^{\circ}$ & $176.1(4)^{\circ}$ \\
$*,-x,-0.5+y, 1-z$ &
\end{tabular}


Figure S8. ORTEP view of the asymmetric unit of $\left[\mathrm{PPh}_{4}\right]_{3}\left\{\mathrm{Mo}(\mathrm{NCSe})_{6}\right\} \cdot \mathrm{CH}_{3} \mathrm{CN}$. Selected bond lengths $(\AA)$ and angles $\left(^{\circ}\right)$ patterning to the anionic units: Mo-N, (range) 2.095(2) to $2.115(2)$; N-C, (range) $1.154(3)$ to $1.161(3)$; C-Se, (range) 1.770(3) to 1.784(3) ; MoN1-C1, 175.7(2); Mo-N2-C2, 175.4(2); Mo-N3-C3, 174.2(2); Mo-N4-C4, 172.7(2); Mo-N5-C5, 172.7(2); Mo-N6-C6, 171.1(2) .

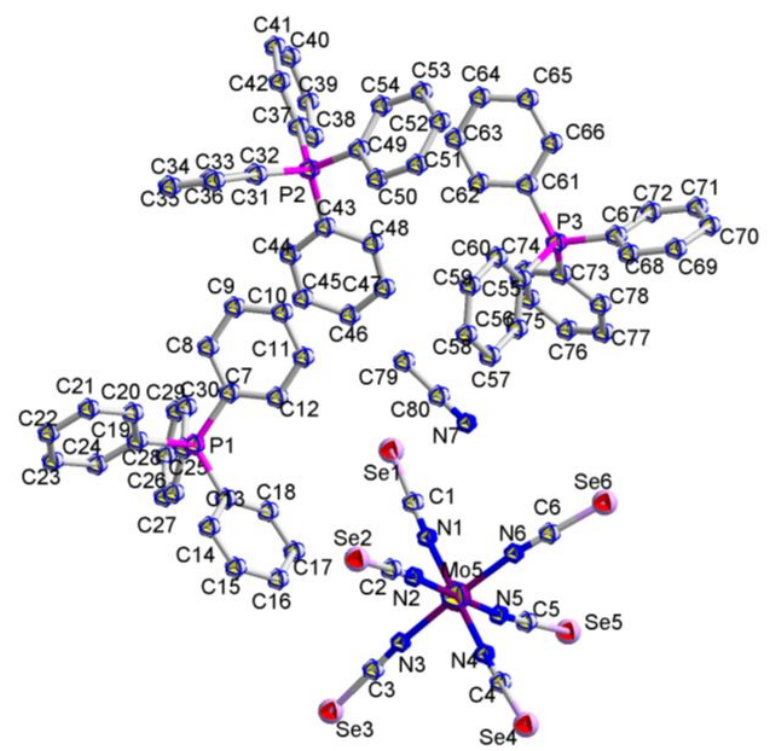

Figure S9. Ladder type organization of the $\left\{\mathrm{Mo}(\mathrm{NCSe})_{6}\right\}^{3-}$ complexes in the crystal of $\left(\mathrm{PPh}_{4}\right)_{3}\left\{\mathrm{Mo}(\mathrm{NCSe})_{6}\right\} \cdot \mathrm{CH}_{3} \mathrm{CN}$, the shortest $\mathrm{Se} \cdots \mathrm{Se}$ separations are materialized by

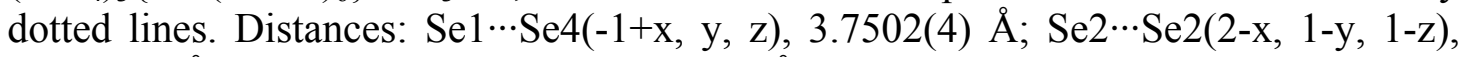
$3.3757(4) \AA$; Se4 $\cdots \operatorname{Se} 1(1+\mathrm{x}, \mathrm{y}, \mathrm{z}), 3.7502(4) \AA$.

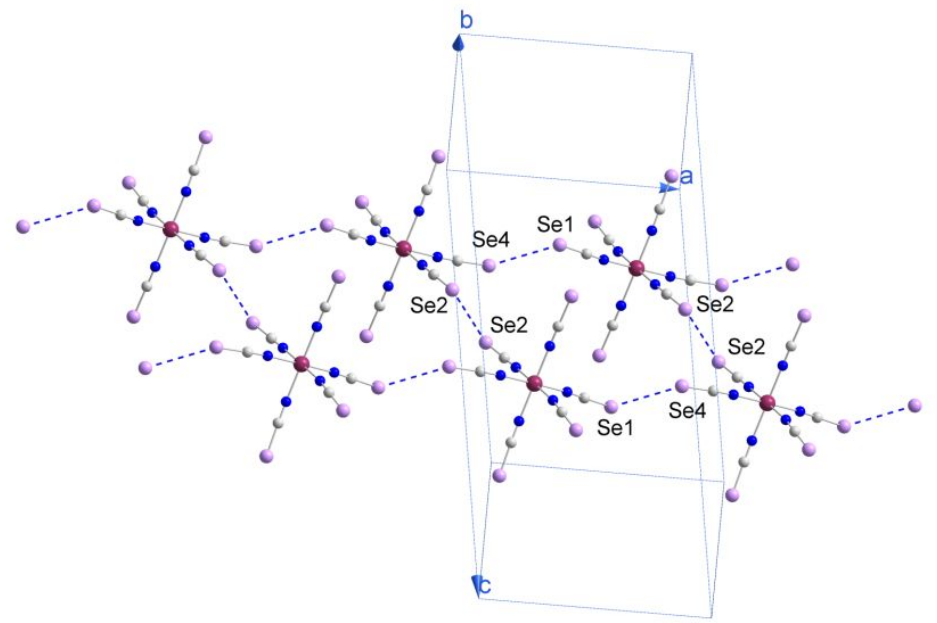


Figure S10 1D-[ $\left.\left\{\mathrm{Mo}(\mathrm{NCSe})_{6}\right\}\left\{\mathrm{NiL}^{\mathrm{N} 4}\right\}_{2}(\mathrm{NCS})\right] \cdot \mathrm{CH}_{3} \mathrm{CN}$, 6: ORTEP view of the asymmetric unit and crystal packing. Selected geometric data: distances ( $\AA)$ Ni1-Se1, 2.6769(9); Ni2-Se2, 2.7614(9); Ni1-S1, 2.552(1); Ni2-N15, 2.105(5); Mo-N, 2.084(5)-2.109(4); angles ( $\left.{ }^{\circ}\right)$ Ni1-Se1-C1, 101.6(1); Ni2-Se2-C2, 103.3(2); Ni1-S1-C46, 103.5(2); Mo-N-C, 166.7(4)-177.2(4); Ni2-N15-C46, 155.2(4).
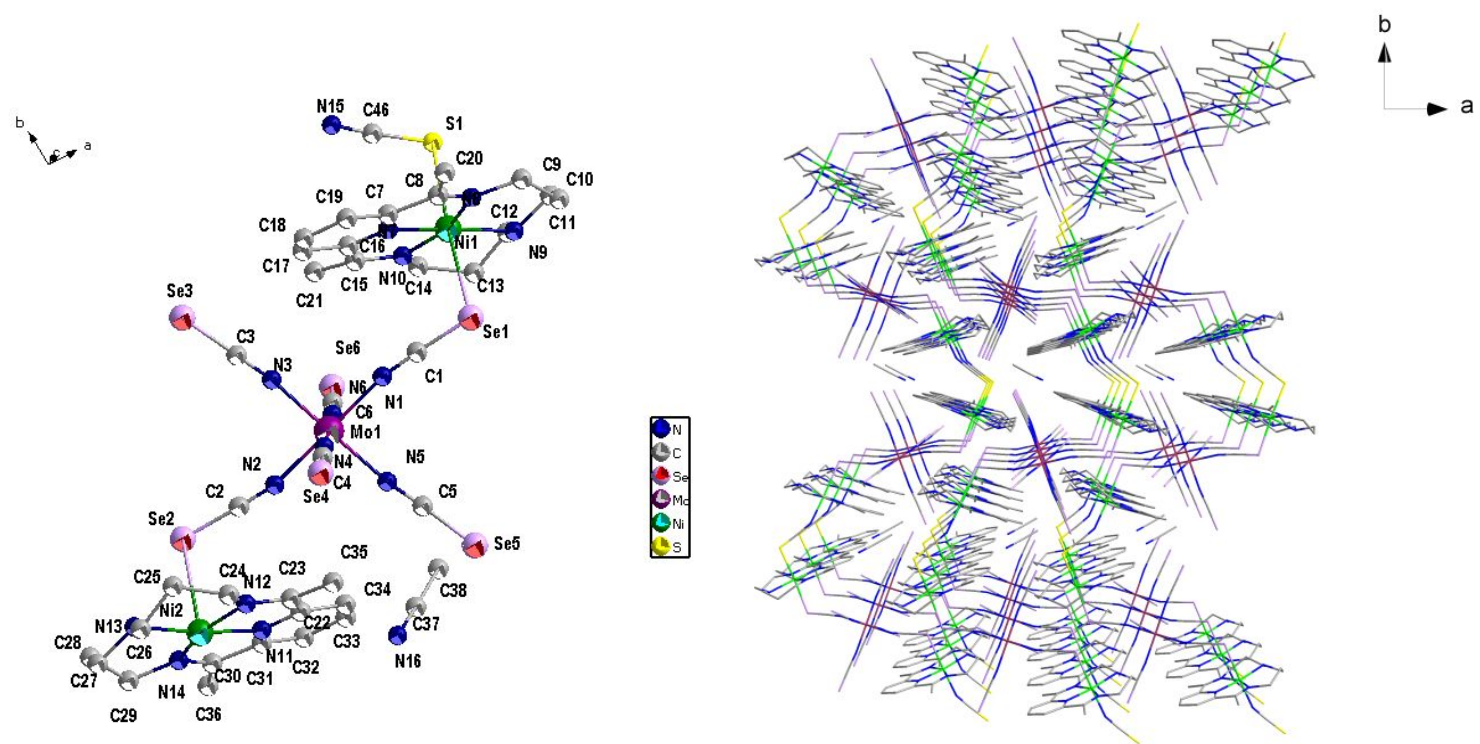

Table S1 Spin density distribution in $\left[\mathrm{Mo}(\mathrm{NCSe})_{6}\right]^{3-}$

\begin{tabular}{|l|l|l|l|l|}
\hline $\mathbf{N}$ & \multicolumn{1}{|c|}{$\mathbf{C}$} & \multicolumn{1}{|c|}{ Se } & \multicolumn{1}{|c|}{ Mo } & \\
\hline-0.081242 & 0.097615 & 0.067972 & 2.474089 & \\
\hline-0.074613 & 0.089112 & 0.061708 & & \\
\hline-0.079583 & 0.099643 & 0.06752 & & \\
\hline-0.08283 & 0.104667 & 0.069896 & & \\
\hline-0.086303 & 0.107056 & 0.072968 & & \\
\hline-0.084777 & 0.103674 & 0.073428 & & \\
\hline-0.081558 & 0.1002945 & 0.06891533 & mean & \\
\hline & & & & \\
\hline-0.05817946 & 0.11149664 & 0.10458243 & (MEAN-MIN)/MEAN \\
\hline-0.08515412 & 0.06741646 & 0.06548132 & (MAX-MEAN)/MEAN \\
\hline
\end{tabular}


Figure S11 Experimental (o) and calculated (-) $\chi_{M} T$ versus $T$ and $M$ versus $H(2 \mathrm{~K})$ behavior for $\left[\mathrm{PPh}_{4}\right]_{3}\left\{\mathrm{Mo}(\mathrm{NCSe}\}_{6} \cdot \mathrm{CH}_{3} \mathrm{CN}\right.$. Best fit parameters: $g=1.9290 \pm 0.0008, D=3.7 \pm 0.1 \mathrm{~cm}^{-1}$ and $z J$, $=-0.117 \pm 0.03 \mathrm{~cm}^{-1}$.

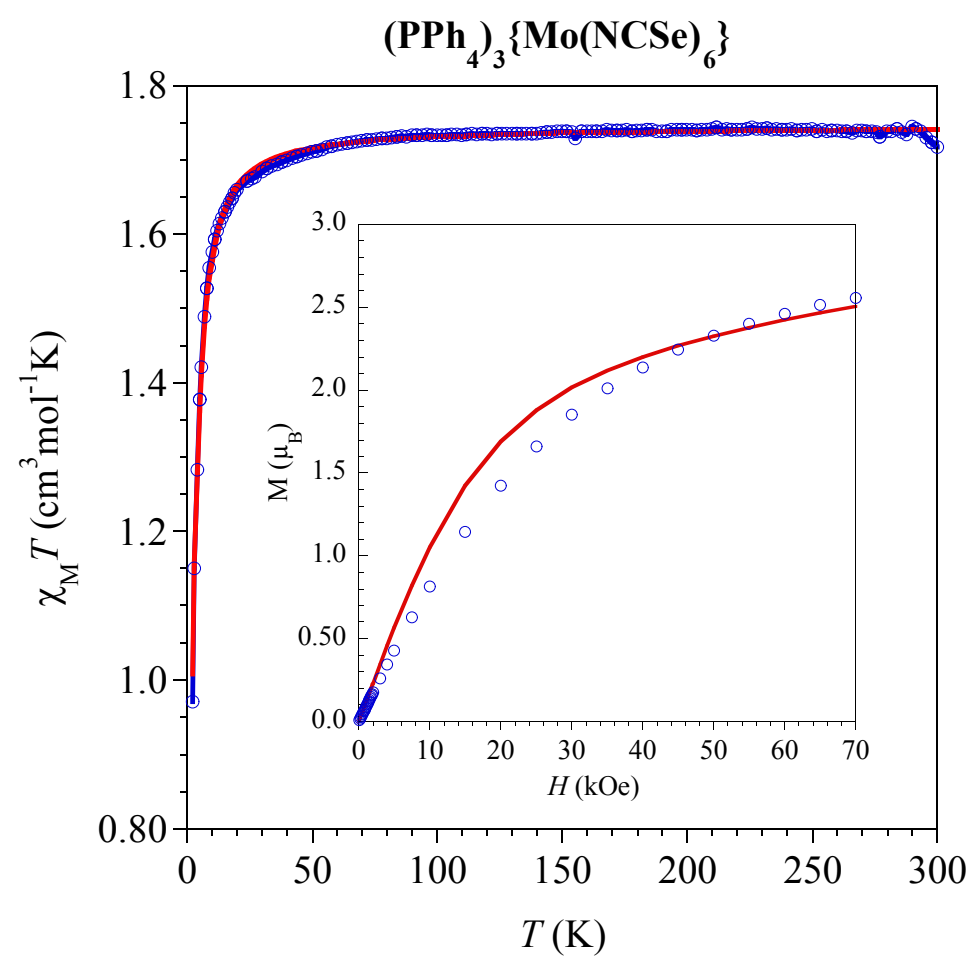

Figure S12 Field dependence of the magnetization for 1, at $2 \mathrm{~K}$. The solid lines is a guide for the eyes.

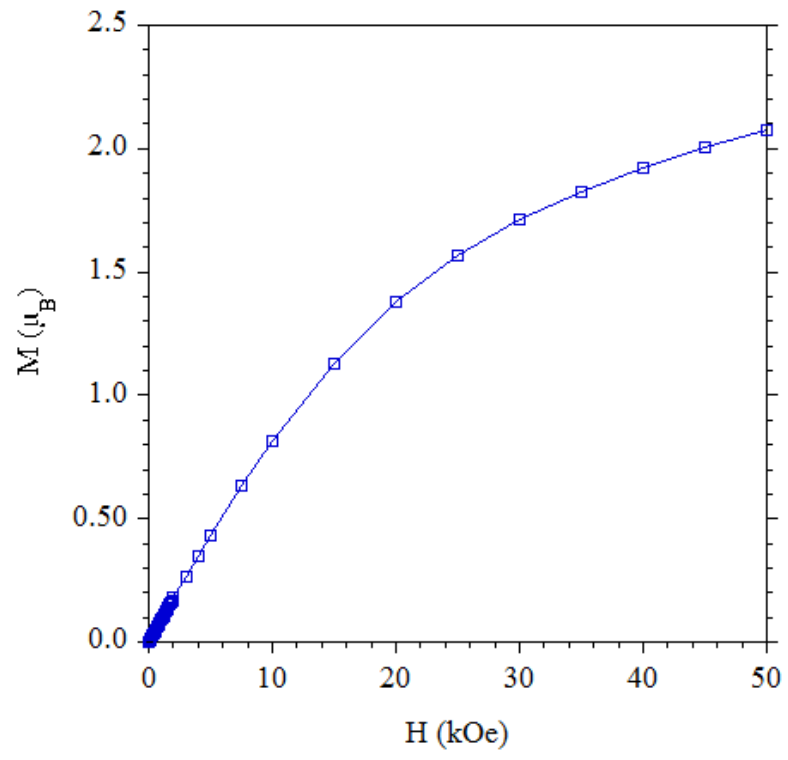


Figure S13 Field dependence of the magnetization for 2, at $2 \mathrm{~K}$. The solid lines is a guide for the eyes.

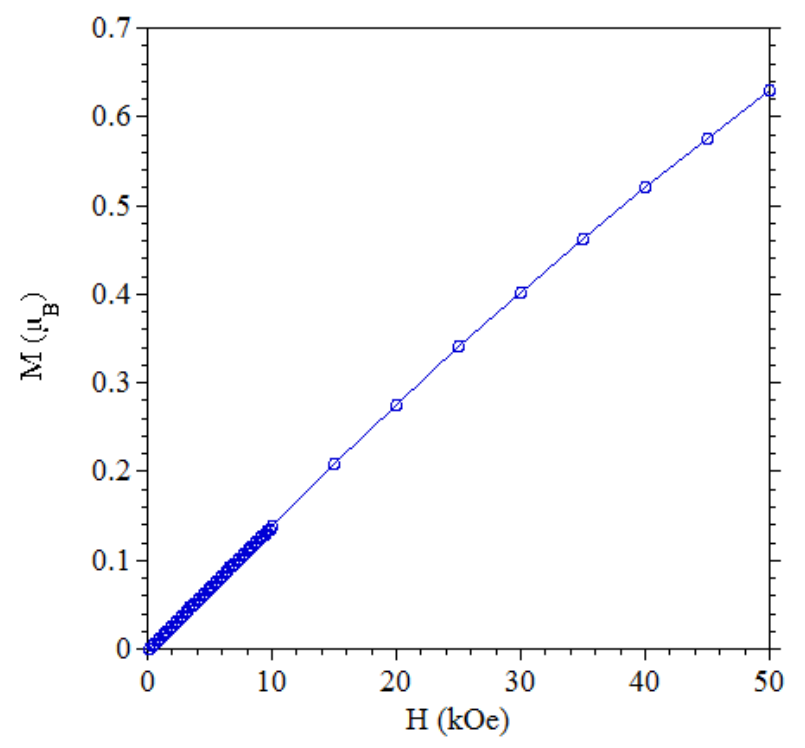

Figure S14: Compound 3: (left) $\chi_{\mathrm{M}}=f(T)$, and (right) field dependence of the magnetization for 3, at $2 \mathrm{~K}$. The solid lines are guides for the eyes.
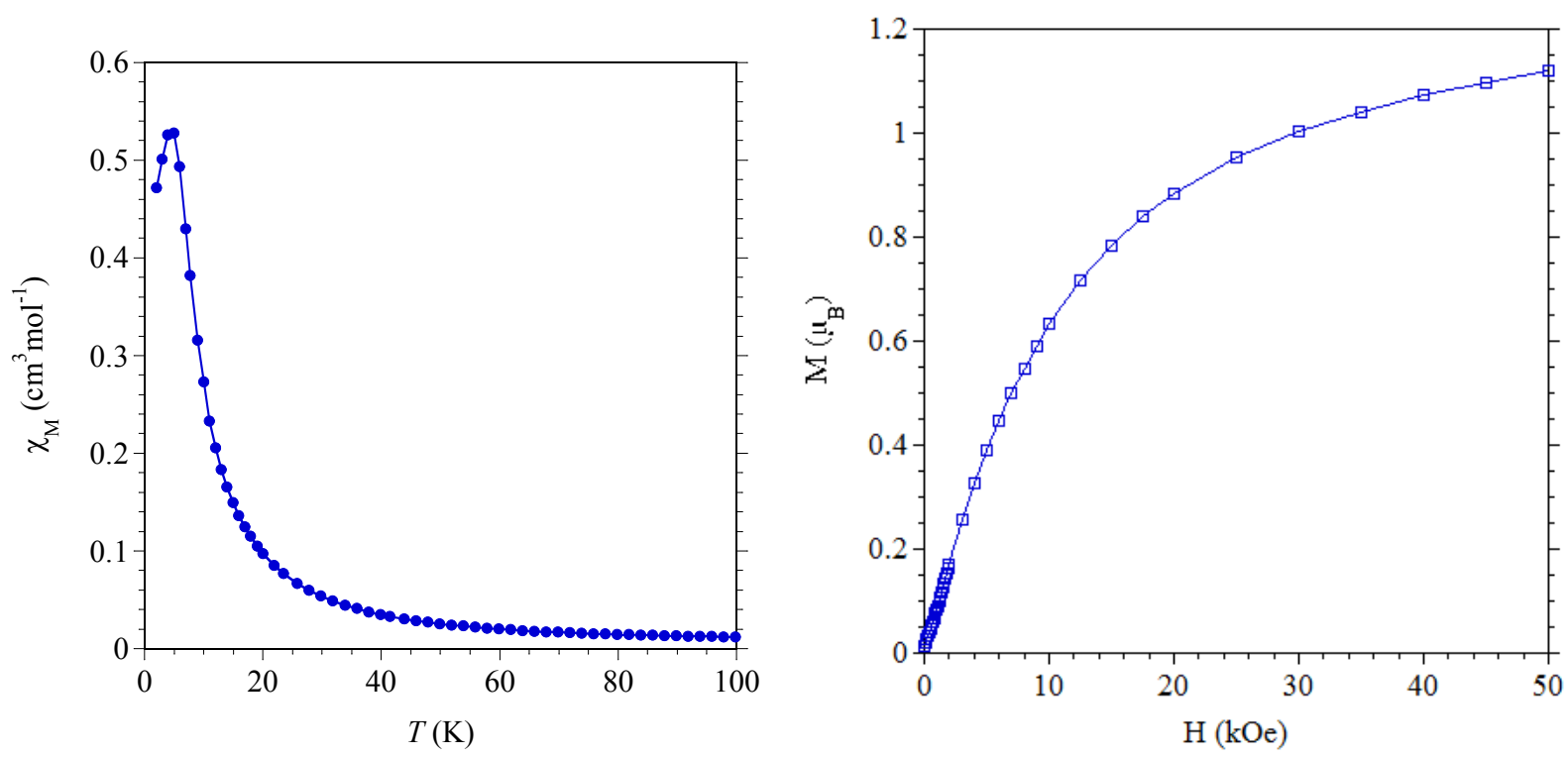
Figure S15. Compound 4: (a) $\chi_{\mathrm{M}}=f(T)$, and (b) field dependence of the magnetization at $2 \mathrm{~K}$ (blue line) and $10 \mathrm{~K}$ (black line); the solid lines are guides for the eyes. (c) AC susceptibility recorded with $H_{\mathrm{AC}}=3$ Oe at a frequency of $100 \mathrm{~Hz}$, in zero field (blue) and in an applied DC field of $8 \mathrm{kOe}$ (red).
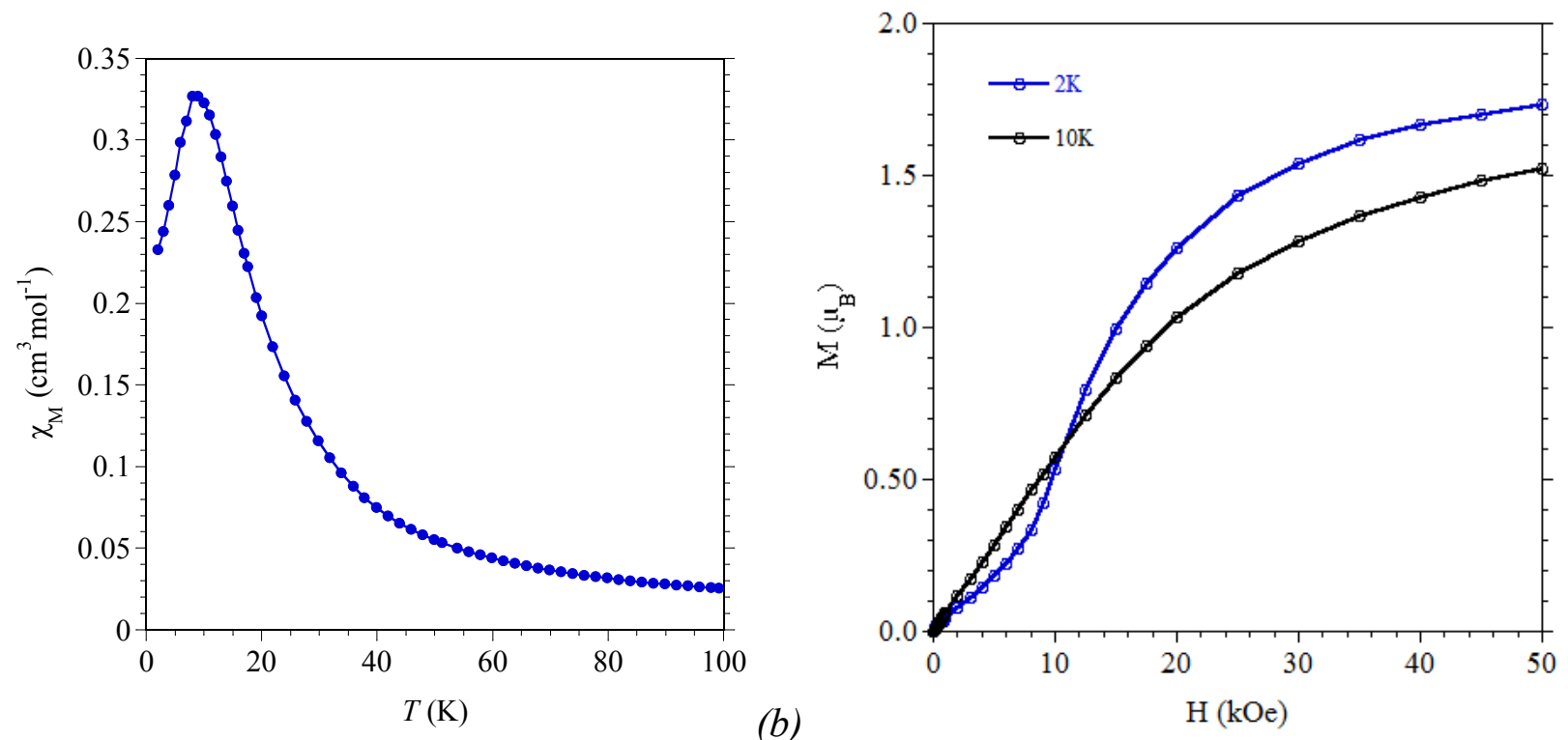

(a)

(b)

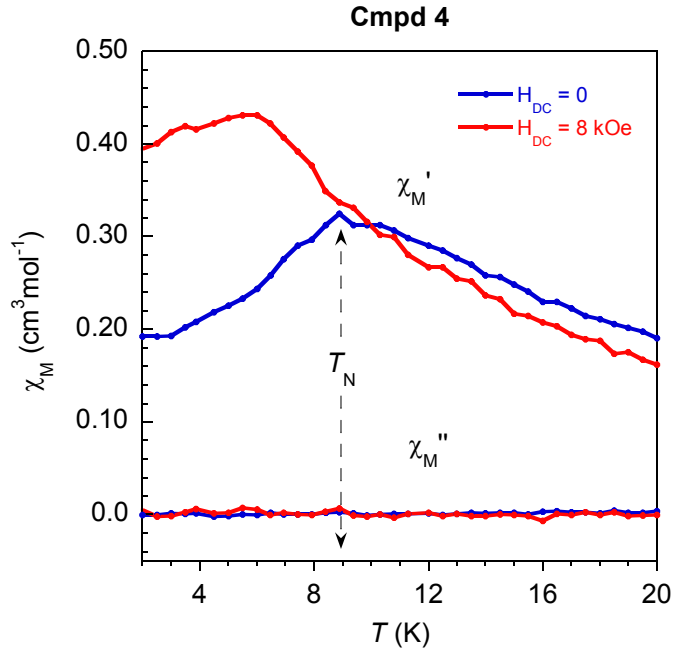

(c) 
Figure S16 Field dependence of the magnetization for $\mathbf{5}$. The solid lines are guides for the eyes.

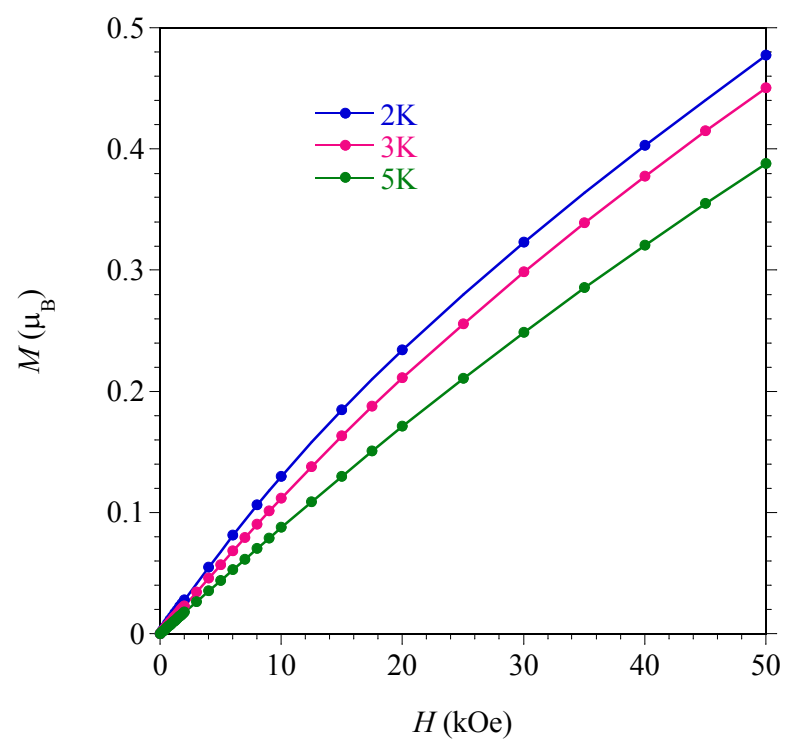

Figure S17 Field dependence of the magnetization for $\mathbf{6}$, at $2 \mathrm{~K}$. The solid line is a guide for the eyes.

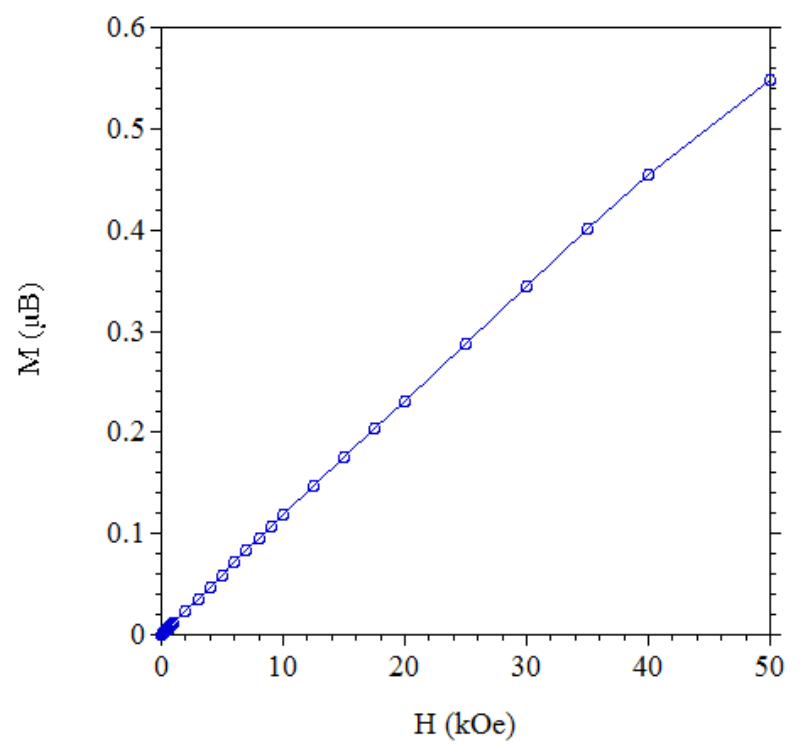


Figure S18. Magnetic behaviour for $\left[\mathrm{CoL}^{\mathrm{N} 4}\left(\mathrm{H}_{2} \mathrm{O}\right)_{2}\right]\left(\mathrm{ClO}_{4}\right)_{2}$. The solid line is a guide for the eyes.

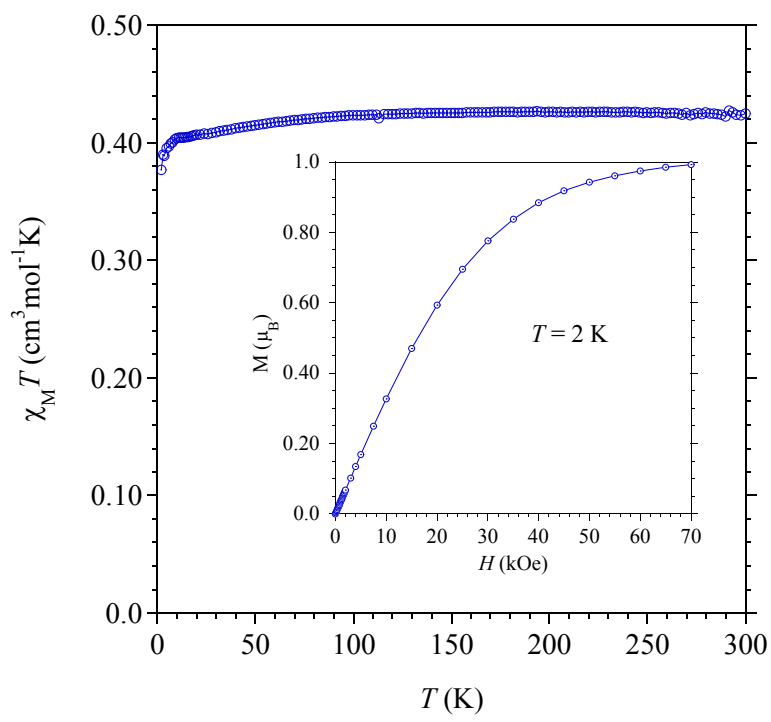


Figure S19. Powder X-Ray patterns for 2-5. In the plots the blue line (up) is the experimental diffractogram obtained from the crystals batch and the red line (down) the calculated diffractogram from the single crystal X-Ray diffraction.

$\left[\left\{\mathrm{Mo}(\mathrm{NCS})_{6}\right\}\left\{\mathrm{NiL}^{\mathrm{N} 4}\right\}\right] \cdot 0.5\left[\mathrm{NiL}^{\mathrm{N} 4}(\mathrm{MeCN})_{2}\right], 2$

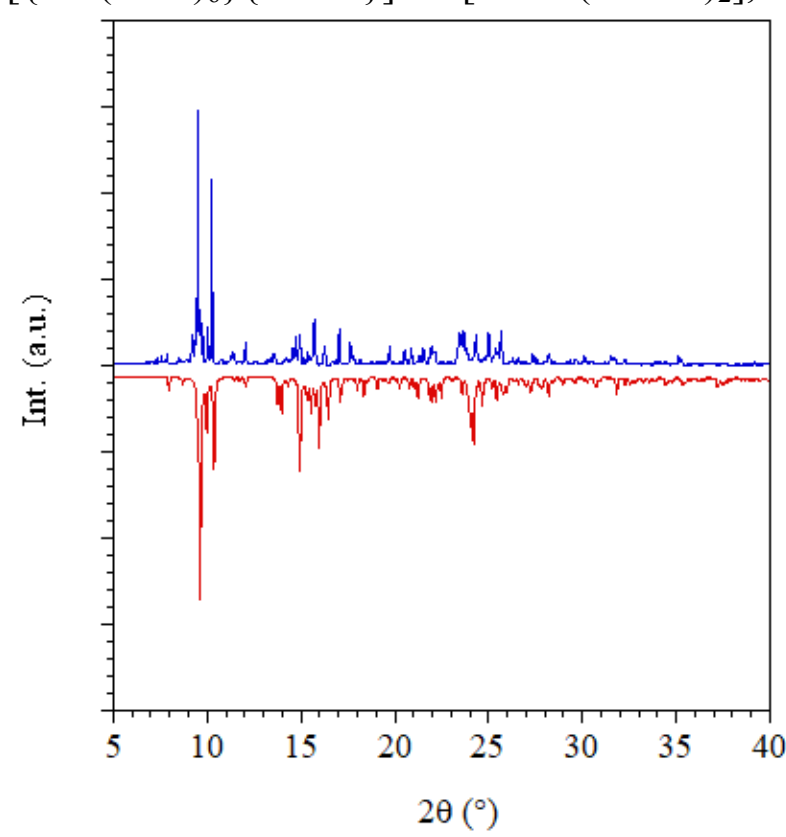

$\left[\left\{\mathrm{Mo}(\mathrm{NCS})_{6}\right\}\left\{\mathrm{Co}^{\mathrm{II}} \mathrm{L}^{\mathrm{N} 4}\right\}\right]\left[\mathrm{Co}^{\mathrm{III}} \mathrm{L}^{\mathrm{N} 4} \mathrm{Br}_{2}\right], 4$

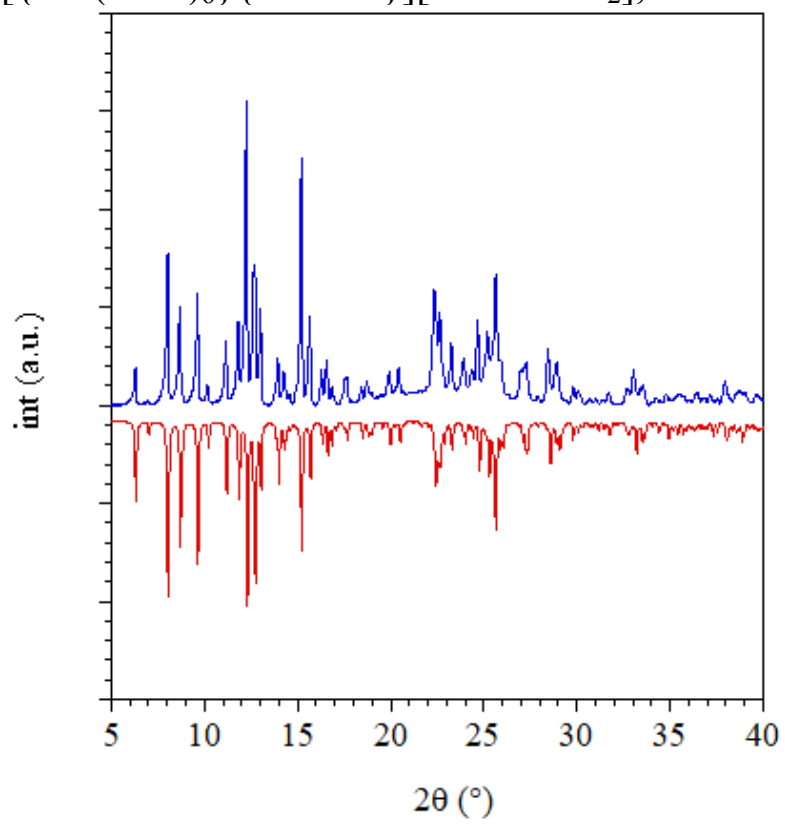

$\left[\left\{\mathrm{Mo}(\mathrm{NCS})_{6}\right\}\left\{\mathrm{NiL}^{\mathrm{N}}\right\}\right]\left[\mathrm{Co}^{\mathrm{III}} \mathrm{L}^{\mathrm{N} 4} \mathrm{Br}_{2}\right], 3$

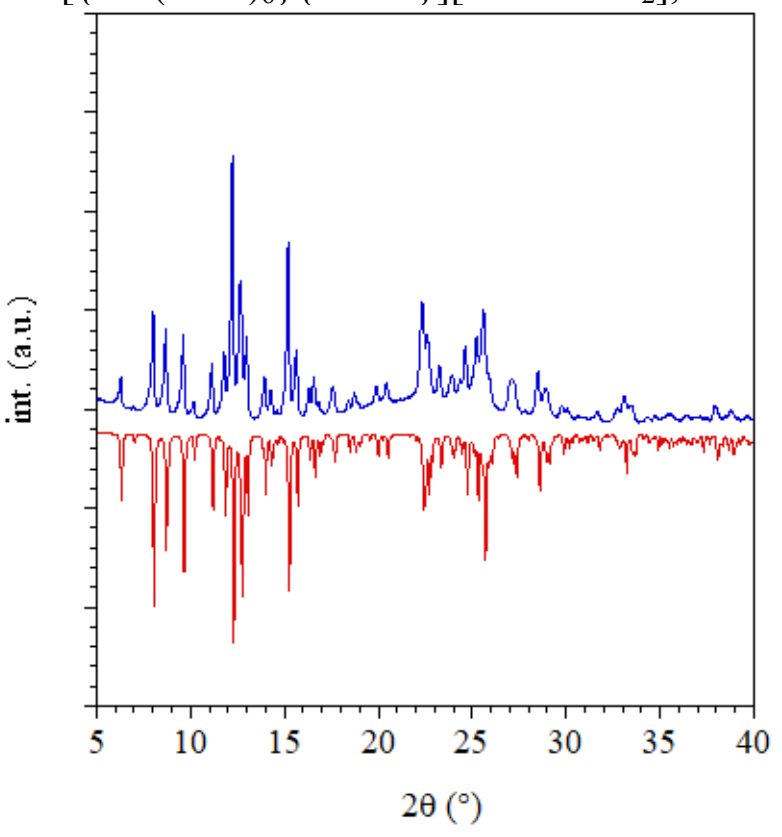

$\left[\left\{\mathrm{Mo}(\mathrm{NCS})_{6}\right\}\left\{\mathrm{Co}^{\mathrm{II}} \mathrm{L}^{\mathrm{N} 4}\right\}_{2}(\mathrm{NCS})\right], \mathbf{5}$

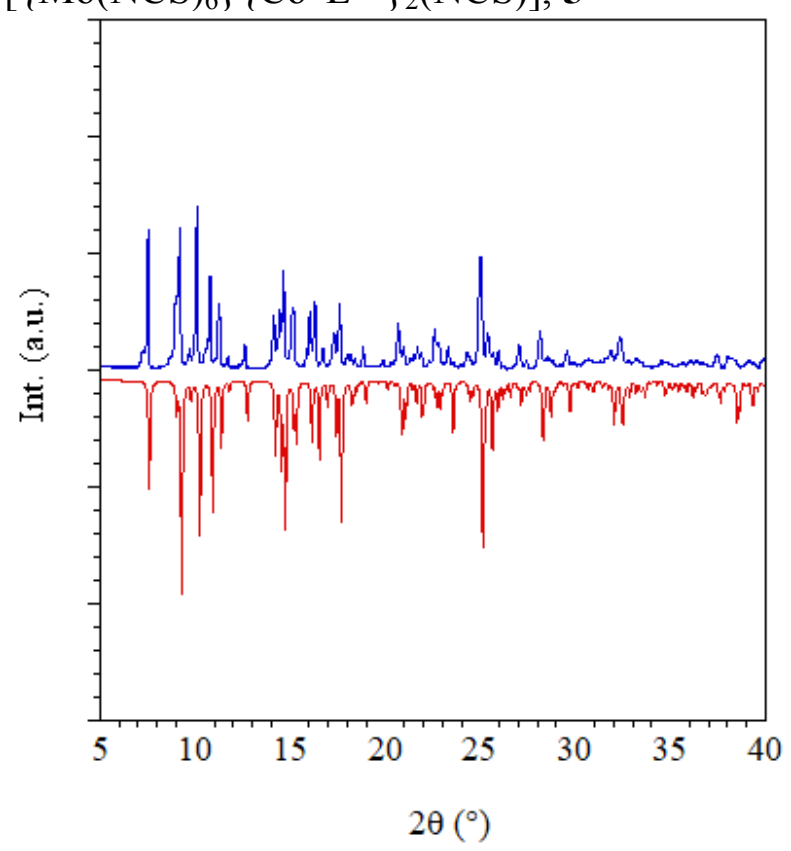




\section{Gaussian reference:}

Gaussian 03, M. J. Frisch, G. W. Trucks, H. B. Schlegel, G. E. Scuseria, M. A. Robb, J. R. Cheeseman, G. Scalmani, V. Barone, G. A. Petersson, H. Nakatsuji, X. Li, M. Caricato, A. Marenich, J. Bloino, B. G. Janesko, R. Gomperts, B. Mennucci, H. P. Hratchian, J. V. Ortiz, A. F. Izmaylov, J. L. Sonnenberg, D. Williams-Young, F. Ding, F. Lipparini, F. Egidi, J. Goings, B. Peng, A. Petrone, T. Henderson, D. Ranasinghe, V. G. Zakrzewski, J. Gao, N. Rega, G. Zheng, W. Liang, M. Hada, M. Ehara, K. Toyota, R. Fukuda, J. Hasegawa, M. Ishida, T. Nakajima, Y. Honda, O. Kitao, H. Nakai, T. Vreven, K. Throssell, J. A. Montgomery, Jr., J. E. Peralta, F. Ogliaro, M. Bearpark, J. J. Heyd, E. Brothers, K. N. Kudin, V. N. Staroverov, T. Keith, R. Kobayashi, J. Normand, K. Raghavachari, A. Rendell, J. C. Burant, S. S. Iyengar, J. Tomasi, M. Cossi, J. M. Millam, M. Klene, C. Adamo, R. Cammi, J. W. Ochterski, R. L. Martin, K. Morokuma, O. Farkas, J. B. Foresman, and D. J. Fox, Gaussian, Inc., Wallingford CT, 2004. 